\title{
The Influence Model of Reliability, Assurance, Tangibles, Empathy, Responsive- ness on Customer Satisfaction and Highway Users Loyalty
}

\author{
Minto Waluyo *, Sumiati, Mohammad Rachman Waluyo \\ Department of Industrial Engineering, Faculty of Engineering, Universitas Pembangunan Nasional "Veteran" \\ Surabaya, East Java, Indonesia
}

*Corresponding author:

E-mail: mintowaluyo@gmail.com

\begin{abstract}
To harmonize the government program of the National Non-Cash Movement (GNNT), PT. Jasa Marga does service improvement by implementing E-Toll. The implementation of the E-toll service is deemed not fully implemented according to the expected goals. This is evident from the existence of several problems that occur such as double detach, the E-toll card is not read by the reader contactless machine, and the gate is not open, all transaction services become dissatisfied. This study aims to determine the effect of reliability, assurance, tangibles, empathy, and responsiveness variables on customer satisfaction and loyalty of toll road users at PT. Jasa Marga Surabaya - Mojokerto Indonesia. Respondents in this study were toll road users who had crossed the Surabaya - Mojokerto toll road at least once, the number of respondents was 120. This study used the Structural Equation Modeling (SEM) method which was processed using AMOS 22 software. The results showed that the Reliability variable had a significant effect on customer satisfaction, Assurance does not have a significant effect on customer satisfaction, Tangible has no significant effect on customer satisfaction, Empathy has no significant effect on customer satisfaction, Responsiveness has a significant effect on customer satisfaction, customer satisfaction has a significant effect on customer loyalty and the model equation is as follows $\mathrm{Y} 2=0.207 \mathrm{X}_{1}+0.114 \mathrm{X}_{2}$ $+0.04 \mathrm{X}_{3}+0.161 \mathrm{X}_{4}+0.191 \mathrm{X}_{5}$
\end{abstract}

Keywords: Structural equation modeling, reliability, assurance, tangibles, empathy, responsiveness, customer satisfaction, loyalty

\section{Introduction}

The Central Bureau of Statistics recorded that the transportation and warehousing sector experienced an increase of $8.95 \%$ in the first quarter of 2018 (Central Bureau of Statistics Indonesian Statistics in the first quarter of 2018) compared to the same period last year, the data above shows that the growth of the transportation sector in Indonesia is increasing. The road congestion makes the freeway as the first choice for mobile transportation due to the smoothness and convenience of the main choices in carrying out its operations.

To support the government program of the National Non-Cash Movement (GNNT) which one of the government programs, PT. Jasa Marga is improving its services by implementing E-Toll (PT. Jasa Marga, 2018) because the toll payment transaction process manually requires a long time. After all, it has to accept money and provide change. Service quality is one of the measurements of success for a company. Besides service quality can be used as one tool to achieve competitive advantage for the company. The better service provided in the customer means the higher the level of success and quality of the company achieved and vice versa

Reliability, assurance, tangibles, empathy, dan responsiveness are the variables that formed from the Quality E-toll implementation service that aims to accelerate transaction services, minimize queues and fulfill the GNNT program (Segara, 2014). But in reality, E-toll service is deemed not to have full run as expected. This is evident from the existence of several problems. A problem that often occurs is that like

How to cite:

Waluyo, M., Sumiati, \& Waluyo, M. R. (2020). The influence model of reliability, assurance, tangibles, empathy, responsiveness on customer satisfaction and highway users loyalty. $1^{\text {st }}$ International Conference Eco- Innovation in Science, Engineering, and Technology. NST Proceedings. pages 243-247. doi: 10.11594/ nstp.2020.0539 
the lack of an E-toll card balance, double detach, the E-toll card is not read by a contactless reader, and the gate cannot open. So, the management asking the researchers to do some research on the model of the influence of E-toll service quality variables on customer satisfaction which has an impact on customer loyalty. PT. Jasa Marga requires the results of E-Toll service quality researches, in which there are inputs to customer satisfaction that have an impact on customer loyalty for sustainability and continuity of E-Toll program decisions.

Five service quality variables, namely reliability, responsiveness, confidence, empathy, and tangible as exogenous variables (Supranto, 2011) Reliability $\left(\mathrm{X}_{1}\right)$ with E-toll operation timeliness indicators in accordance with SOP 4 seconds $\left(\mathrm{X}_{1.1}\right)$ (Amalia, 2017), reader contactless engine performance $\left(\mathrm{X}_{1.2}\right)$, the accuracy of E-toll payments $\left(\mathrm{X}_{1.3}\right)$ (Herry, et al., 2015$)$, the e-toll card is not easily damaged $\left(\mathrm{X}_{1.4)} \mathrm{Re}\right.$ sponsiveness with indicators of officer friendliness, $\left(X_{1.5}\right)$ (Herry $T$. Zuna, et al ,2015), decency officer compensation $\left(\mathrm{X}_{1.6}\right)$, officer knowledge $\left(\mathrm{X}_{1.7}\right)$ Assurance with toll booth indicator $\left(\mathrm{X}_{1.8}\right)$, (Herry, et al., 2015), display of the E-toll tariff and soldo information board $\left(X_{1.9}\right)$ (Herry, et al., 2015), presence Etoll user guide $\left(X_{1.10}\right)$, Emphaty, with call center indicator $\left(X_{1.11}\right)$ (Herry, et al., 2015), Tangible with an indicator of easy access to emergency services $\left(X_{1.12}\right)$ (Herry, et al., 2015), speed of emergency services $\left(\mathrm{X}_{1.13}\right)$ (Herry, et al., 2015), comprehensiveness of emergency damage $\left(\mathrm{X}_{1.14}\right)$ (Herry, et al., 2015), ease of emergency top up.

Satisfaction is the feeling of being happy or disappointed who comes from a comparison between the impression of the performance or the results of a product and the expectations (Panjaitan, 2016). The company will succeed in obtaining a large number of customers if it is judged to provide satisfaction for its customers when the customers are satisfied, there will be a harmonious relationship between the producers and the consumers, creating a good basis for repurchasing and forming word of mouth recommendations that can benefit for the company.

Customer satisfaction is a post-purchase evaluation where alternatives chosen at least give results (outcomes) equal to or exceed customer expectations, while dissatisfaction arises when the results obtained do not meet customer expectations (Arka, et al., 2017), Generally, companies often use to find out customer satisfaction are aspects of service and quality of goods or services provided (Rahmayanty, 2010), an indicator of customer satisfaction (Tjiptono, 2004), consisting of: Overall satisfaction $\left(Y_{1.1}\right)$ (Fornell, 1996), confirmation of expectation $\left(\mathrm{Y}_{1.2}\right)$ (Fornell, 1996), confirmation expectations $\left(\mathrm{Y}_{1.3}\right)$ (Fornell, 1996), and comparison to the ideal ( $\left.\mathrm{Y}_{1.4}\right)$ (Fornell, 1996), Customer Loyalty means loyalty, which is someone's loyalty to an object. Loyalty as a condition that the customer has a positive attitude towards a brand, commits to the brand, and intends to continue its purchases in the future. Loyalty shows the tendency of customers to use a particular brand with a high level of consistency (Zain, 2013), this means loyalty is always related to customer preferences and actual purchases. Customer Loyalty indicators consist of: Share Info ( $\left.\mathrm{Y}_{2.1}\right)$ (Anthony, et al., 2003), Say positive things ( $\left.\mathrm{Y}_{2.2}\right)$ (Anthony, et al., 2003), Recommended friends ( $\left.\mathrm{Y}_{2.3}\right)$ (Anthony, Robert N. et al. 2003), Continuous Purchasing $\left(\mathrm{Y}_{2.4}\right)$ (Anthony, et al., 2003) and Purchase additional service (Y 2.5$)$ (Anthony, et al., 2003).

The objectives of this study are as follows:

1. Find the significant effect of E-Toll service quality variables which are formed from variable reliability, assurance, tangibles, empathy, and responsiveness to the variable customer satisfaction.

2. Find the significant influence of customer satisfaction variables on customer loyalty variables.

3. Find the simultaneous equation of the model of the influence of E-toll service quality variables on customer satisfaction that has an impact on customer loyalty.

\section{Research Method}

This research was conducted at PT. Jasamarga, especially in its subsidiaries, namely PT. Jasamarga Surabaya Mojokerto (PT. Jasa Marga, 2018). The research data was obtained from the distribution of online questionnaires, the distribution obtained 120 respondents using the maximum likelihood (ML) technique (Waluyo, 2016) the data was sufficient, with the following questionnaire filler criteria ever 
crossing the Surabaya-Mojokerto toll road Indonesia uses E-Toll at least once. The measurement scale used in this questionnaire is the Likert scale of 1 to 5 (Nazir, 2005). Sampling uses non-probability sampling, data management uses the Amos 22 toll (Arbuckle \& Wothke, 2013), the tests carried out include validity, significance, correlation, regression, reliability, and model (Tabachnick \& Fidell, 1996). Structural Equation Modeling (SEM) method as its toll and three processing processes namely measurement, structural, and modification models.

\section{Result and Discussion}

The measurement model can be the value of Goodness of Fit and Cut-off Value is Chi-square = 412,070, Probability level $=0,000, \mathrm{Cmin} / \mathrm{df}=1,784, \mathrm{RMSEA}=0.081, \mathrm{GFI}=0.782, \mathrm{AGFI}=0.717$, $\mathrm{CFI}=0.906, \mathrm{TLI}=0.888$. From the results of the model test compared to the critical value, four criteria have not good, namely Chi-Square, Probability, GFI, and AGFI. While the validity and reliability test shows all valid and reliable indicators because the SEM tool has a modification device. The researcher continues the run structural model process. The results of the Goodness of Fit and Cut-off Value are Chi-square $=745,387$, Probability level $=0,000, \mathrm{Cmin} / \mathrm{df}=3,030, \mathrm{RMSEA}=0.131, \mathrm{GFI}=0.636$, AGFI $=0.557, \mathrm{CFI}=0.741, \mathrm{TLI}=0.709$. From the results of the model test compared to the critical value there are eight indicators that have not good, the researchers continue the process of running the result modification model as shown below.

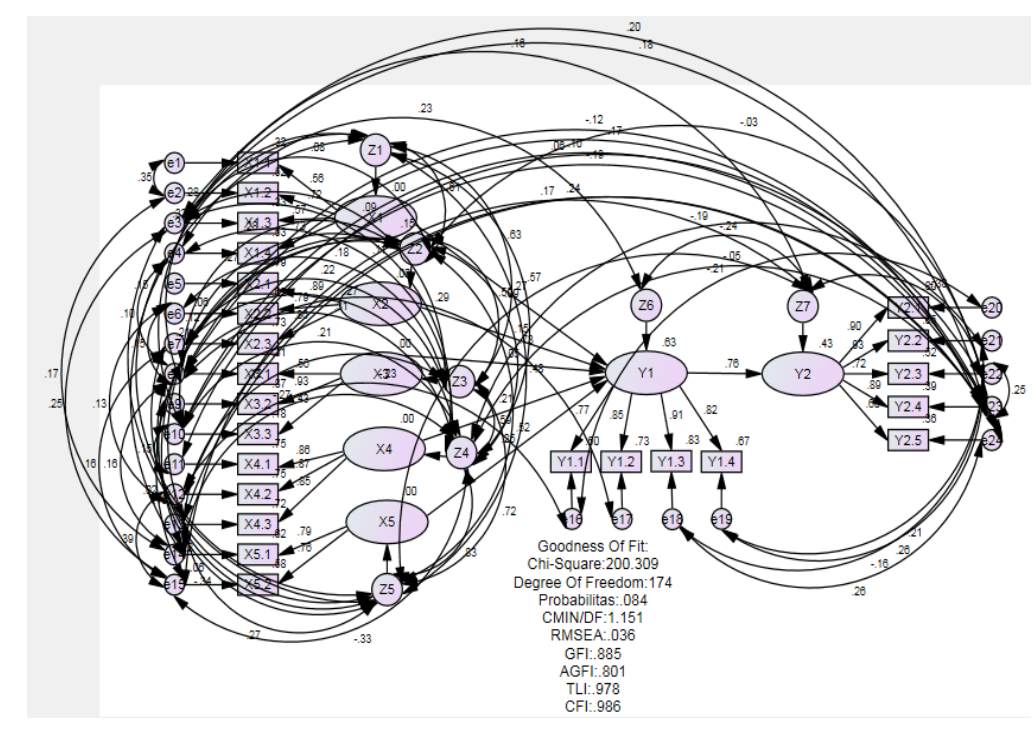

Figure 1. Model modification

The step of modifying the reference through the largest modification index (MI) and having a strong reference theory can reduce the chi-square value $\left(\mathrm{X}^{2}\right)$ if it does not meet the criteria, select the second largest MI, and so on (Bentler \& Bonett, 1980). The results of the evaluation modification model obtained Goodness of Fit and Cut-off Value is Chi-square $=200,309$, Probability level $=0.084, \mathrm{Cmin} / \mathrm{df}$ $=1,161, \mathrm{RMSEA}=0.036, \mathrm{GFI}=0.885, \mathrm{AGFI}=0.801, \mathrm{CFI}=0.986, \mathrm{TLI}=0.978$. From the results of the model test, which is compared with the critical value, all criteria are good, except GFI and AGFI which can be interpreted as close (marginal). And in the validity and reliability test, several variables and indicators are invalid and unreliable. 
The following is the hypothesis test table of the model of the influence of E-Toll service quality on customer satisfaction which has an impact on the loyalty of toll road users:

Tabel 1. Validation esitimate, signicancy and standardize regression weight

\begin{tabular}{|c|c|c|c|c|c|c|c|c|}
\hline & Estimate & S.E & C.R & $2 \mathrm{SE}$ & $\mathrm{P}$ & Valid & Sig & $\begin{array}{l}\text { Standard- } \\
\text { ized Re- } \\
\text { gression } \\
\text { Weight }\end{array}$ \\
\hline $\begin{array}{l}\mathrm{Y} 1 \leftarrow \\
\mathrm{X} 3\end{array}$ & 0.066 & 0.198 & 0.335 & 0.396 & 0.738 & $\begin{array}{l}\text { INVA- } \\
\text { LID }\end{array}$ & Not Sig. & 0.053 \\
\hline $\begin{array}{l}\mathrm{Y} 1 \leftarrow \\
\mathrm{X} 4\end{array}$ & 0.198 & 0.213 & 0.93 & 0.426 & 0.352 & $\begin{array}{l}\text { INVA- } \\
\text { LID }\end{array}$ & Not Sig. & 0.214 \\
\hline $\begin{array}{l}\mathrm{Y} 1 \leftarrow \\
\mathrm{X} 5\end{array}$ & 0.249 & 0.2 & 1.246 & 0.4 & 0.213 & VALID & $\begin{array}{l}\text { Signifi- } \\
\text { cant }\end{array}$ & 0.253 \\
\hline $\begin{array}{l}\mathrm{Y} 1 \leftarrow \\
\mathrm{X} 1\end{array}$ & 0.272 & 0.236 & 1.153 & 0.472 & 0.249 & VALID & $\begin{array}{l}\text { Signifi- } \\
\text { cant }\end{array}$ & 0.274 \\
\hline $\begin{array}{l}\mathrm{Y} 1 \leftarrow \\
\mathrm{X} 2\end{array}$ & 0.134 & 0.309 & 0.432 & 0.618 & 0.665 & $\begin{array}{l}\text { INVA- } \\
\text { LID }\end{array}$ & Not Sig. & 0.152 \\
\hline $\begin{array}{l}\mathrm{Y} 2 \leftarrow \\
\mathrm{Y} 1\end{array}$ & 0.901 & 0.135 & 6.667 & 0.27 & & VALID & $\begin{array}{l}\text { Signifi- } \\
\text { cant }\end{array}$ & 0.755 \\
\hline
\end{tabular}

Reliability test results of all variables ( $\geq 0.7)$, the hypothesis is found to have a significant effect on customer satisfaction, Assurance does not have a significant effect on customer satisfaction, Tangible has no significant effect on customer satisfaction, Empathy has no significant effect on customer satisfaction, Responsiveness has a significant effect on customer satisfaction. The results of this study do not fully support the study (Leong, et al., 2015). Customer satisfaction has a significant effect on customer loyalty. The results of this study support from research (Zain, 2013).

Based on the equation $\mathrm{Y} 1=0.274 \mathrm{X} 1+0.152 \mathrm{X} 2+0.053 \mathrm{X} 3+0.214 \mathrm{X} 4+0.253 \mathrm{X} 5$, the quality of E-Toll services has a direct effect on customer satisfaction. The equation $\mathrm{Y} 2=0.207 \mathrm{X} 1+0.115 \mathrm{X} 2$ $+0.04 \mathrm{X} 3+0.161 \mathrm{X} 4+0.191 \mathrm{X} 5$, then service satisfaction has a direct effect with the regression coefficient of 0.755 has a significant influence on customer loyalty because the Surabaya - Mojokerto toll road is built to solve very heavy congestion on the road Surabaya - Mojokerto, customer loyalty becomes smaller due to the effect of regression composed of service quality variables to customer satisfaction which makes it not significantly significant in the equation.

The indicator for the Assurance variable has a large influence is the friendliness of the officers and knowledge of the officers. The indicator on the Tangible variable that has a large influence is the display of the toll booth which is good and the number is adequate. Indicators on Empathy variables that have a large influence are call centers as information service facilities, ease of getting emergency services, and speed of service for emergency staff. The indicator of the variable customer satisfaction that has a major influence is the change in the non-cash payment system following what is expected from observations of the policy of changes in pay to the implementation of the E-toll to continue to be implemented to other people and use the E-toll regularly. 


\section{Conclusion}

From this study, we can draw some conclusions, that the model of the effect of E-Toll service quality variables formed from variable reliability, responsiveness, confidence, empathy, and tangible on customer satisfaction and customer loyalty include:

1. Reliability and tangible variables have a significant effect on customer satisfaction variables, variable responsiveness, confidence, empathy does not have a significant effect on customer satisfaction variables.

2. Variable customer satisfaction has a significant effect on variable customer loyalty.

3. Simultaneous equation model influence reliability, assurance, tangible, empathy, responsiveness to customer satisfaction and loyalty of toll road users $\mathrm{Y} 2=0.207 \mathrm{X} 1+0.115 \mathrm{X} 2+0.04 \mathrm{X} 3$ $+0.161 \mathrm{X} 4+0.191 \mathrm{X} 5$

\section{References}

Amalia, G.P. (2017). Effectiveness of Electronic Toll (E-toll) By PT. Jasa Marga Surabaya. Journal of Nation Administration Unesa, 1, 1-8 Anthony, R. N., John, D., Norton, M. B. (2003). Management Control System. Jakarta: Binarupa Aksara.

Arbuckle, J. L., \& Wothke, W. (2013). Amos 22 User's Guide, Small Waters Corporation. Chicago: Smallwaters.

Arka, A., Leonardo, B. H., Edward, G. P., \& Darsin, D. (2017). Peningkatan Kualitas Pelayanan, Fasilitas dan Harga Untuk Kepuasan Pelanggan Agar Tercipta Loyalitas Pelanggan. Journal of Management, 3(3), 1-6

Bentler, P. M., \& Bonett, D. G (1980). Significance tests and goodness of fit in the analysis of covariance structures. Psychological Bulletin, $88,588-606$

Central Bureau of Statistics. Indonesian Statistics in the first quarter of 2018. Jakarta: BPS.

Fornell, C., Johnson, M. D., Anderson, E. W., Cha, \& Bryant, B. E. (1996). The American Customer Satisfaction Index: Nature, Purpose, and Findings. Journal of Marketing, 60, 6-12

Herry, T. Z., Sigit, P.H., \& Hedi, R. (2015). Attributes of Highway Services in Improving the Quality of Driving on the Makassar Highway. Journal of HPJI, 1, 115-126

Leong, L. Y., Tech, S. H., Voon, H. L., \& Keng, B. O. (2015). An SEM artificial neural network analysis of the relationships between SERVPERF, customer satisfaction and loyalty among low cast and full-service airline. Expert Systems with Application, 35(2015), 90105.

Nazir, M. (2005). Research methods. Jakarta: Ghalia Indonesia.

Panjaitan, J. E. (2016). The effect of service quality on customer satisfaction at JNE Bandung. Journal of Management, 11(2), 1-7.

PT. Jasa Marga. Sekilas Jasa Marga. Retived from http://www.jasamarga.com/public/id/ infoperusahaan/ProfilPerusahaan/Overview.aspx. on March 2018

Rahmayanty, N. (2010). Excellent service management. Yogyakarta; Graha Ilmu.

Segara, T. (2014). Bank Indonesia Mencanangkan Gerakan Nasional Non Tunai. Retrived from https://www.bi.go.id/id/ruang-media/siaranpers/Pages/sp 165814.aspx on March 2018

Supranto, J. (2011). Measuring the level of customer satisfaction to increase market share. Jakarta: Rineka Cipta. 